\title{
Synovial giant cells in rheumatoid arthritis and other joint diseases
}

\author{
A. K. BHAN AND S. ROY \\ Department of Pathology, All-India Institute of Medical Sciences, New Delhi-16, India
}

The presence of a distinctive multinucleated giant cell has recently been described in the sjnovial membrane in rheunatoid arthritis and its diagnostic significance has been stressed (Grimley and Sokoloff, 1966; Donald and Kerr, 1968). Although passing reference to the presence of multinucleated synovial cells in rheumatoid arthritis was made by Hirohata and Kobays.s'i (1964), the occurrence of any stich cell has not been mentioned in textbooks descriting the pathological features of joint diseases (Allison and Ghormley, 1931; Collins, 1949; Copeman, 1964; Gardner, 1965). Similar giant cells have not so far been observed in any other arthritic condition in man.

We have studied the synovial membrane from cases of rheumatoid arthritis and various other arthritic conditions, including tuberculous arthritis, to find out the presence of giant cells and the results are reported here.

\section{Material and methods}

Synovial biopsies from 26 cases of 'definite' or 'classical' rheumatoid arthritis (Ropes, Bennett, Cobb, Jacox, and Jessar, 1959), twenty cases of tuberculous synovitis, three cases of villonodular synovitis, and eight cases of traumatic arthritis were examined. Synovial membranes collected post mortem from ten normal individuals without any joint disease and from ten cases of osteoarthritis were also included in this study.

The cases of rheumatoid arthritis were of both sexes and their ages varied from 19 to 65 years. The duration of disease ranged from 9 months to 12 years. Patients with tuberculous arthritis were also of both sexes (age range 8 to $42 \mathrm{yrs}$; duration of disease $3 \mathrm{mths}$ to $4 \mathrm{yr}$ ). The duration of the traumatic arthritis ranged from 3 mths to 2 yrs.

In the 26 cases of rheumatoid arthritis, serological

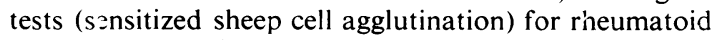
factor werz positive in eleven cases and negative in eleve.1; in the remaining four patients the test was not carried out. Serological tests for rheumatoid factor were negative in the six cases of tuberculous arthritis in which they were performed.

The specimens were fixed in 10 per cont. neutral formalin processed for li zht microscopy and $6 \mu$ faraffin sections were stained with haematoxylin and eosin. The representative sections were also stained with periodic acid-Schiff, with and without diastase digestion, Alcian blue ( $\mathrm{pH} 2 \cdot 6$ ), and colloidal iron stain (McManus and
Mowry, 1960) to study the cytoplasmic characteristics of the giant cells. Two or three blocks were examined from most of the cases.

\section{Results}

Morphology and location of synovial giant cell;

The synovial giant cells obse: ved in all the conditions described below have similar mo phological features. They are round or ovoid containing slightly basoptilic cytoplasm and four to ten round o: oval vesicular or densely staining nuclei, situated at the periphery of the cells (Figs 1, 2, 3, and 4). The giant cells are usually located in the superficial sub-synovial tissue just deep to the deeper layer of the synovial lining cells but are present at times within the synovial layer (Fig. 5, overleaf). They are rarely seen very deep in the sub-synovial tissue. Not infrequently, binucleated cells, which appear to be the transitional forms from the synovial lining cells to the fully developed giant cells, are seen (Figs 1 and 5). These giant cells can be easily distinguished from the Langhans's giant cells of tuberculosis which are often much larger than the synovial giant cells, have abundant eosinophilic cytoplasm, and are usually present much deeper in the sub-synovial tissue in ivlation to the granulomas.

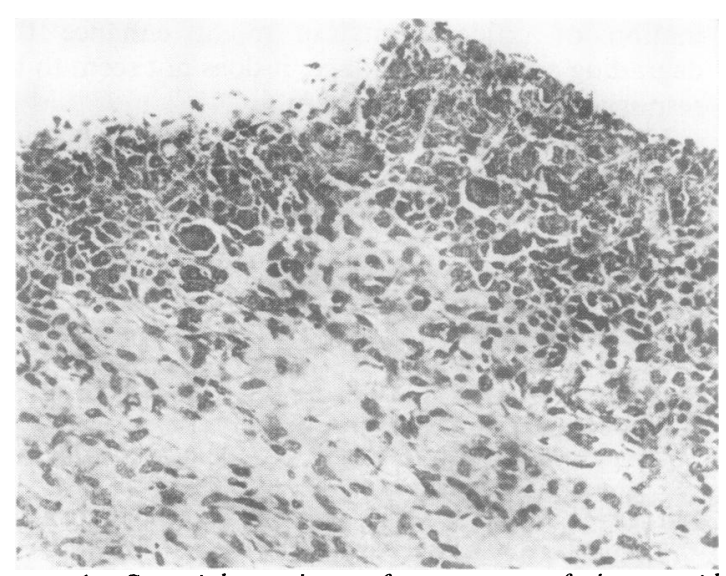

FIG. 1 Synovial membrane from a case of rheumatoid arthritis, showing many giant cells in an area of wellmarked hyperplasia of the synovial intimal cells. Haematoxylin and eosin. $\times 160$. 


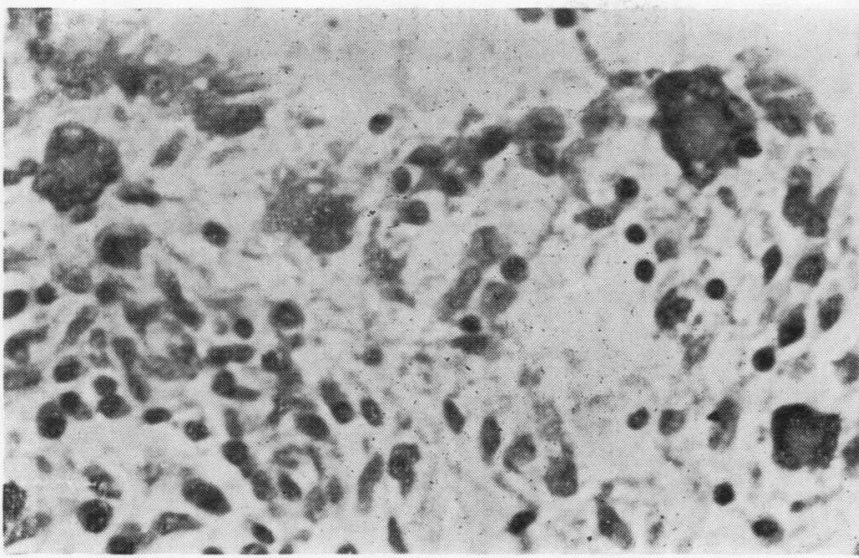

FIG. 2 Synovial membrane from a case of tuberculous arthritis, showing giant cells in areas with no synovial intimal cell hyperplasia. There was no evidence of granuloma in the vicinity. Haemotoxylin and eosin. $\times 530$.

The giant cells usually occur in groups and are usually present in areas showing moderate or marked synovial cell proliferation. However, the giant cells can sometimes be seen in areas with no evidence of synovial cell hyperplasia (Fig. 2).

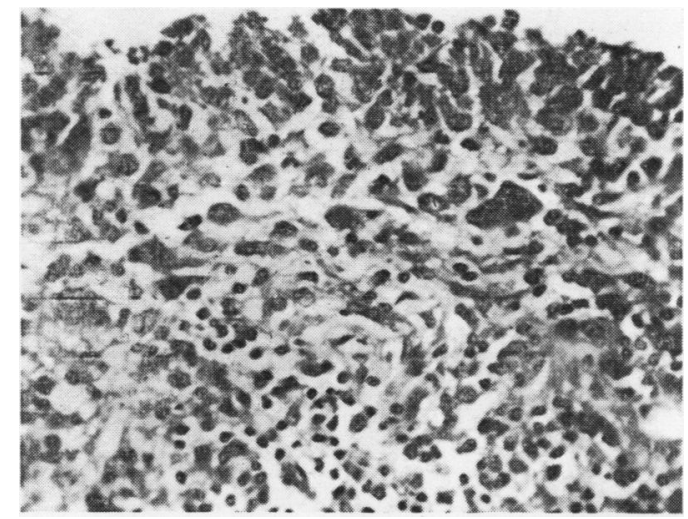

FIG. 3 Synovial membrane from a case of tuberculous arthritis, showing giant cells located at the superficial sub-synovium in an area of mild synovial cell proliferation. No granuluma was present in the vicinity. Haematoxylin and eosin. $\times 330$.

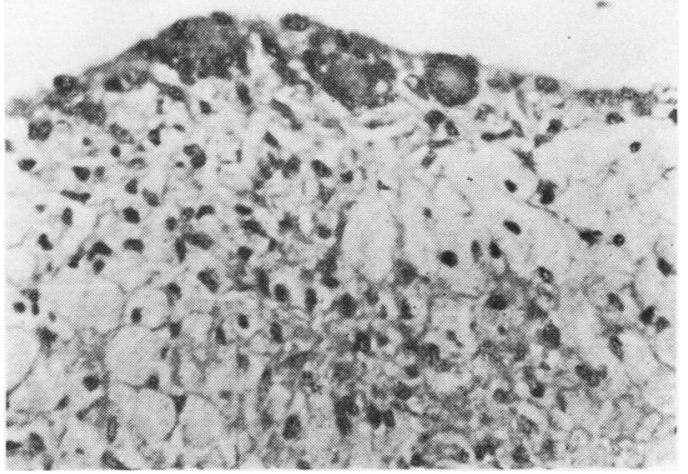

FIG. 4 Synovial membrane from villonodular synovitis, showing giant cells in the intimal layer and numerous foam cells in the sub-synovial tissue. Haematoxylin and eosin. $\times 330$.
On periodic acid-Schiff staining, the cytoplas.n of the giant cells gives a strongly positive reaction which is resistant to diastase digestion. The cytoplasm is either negative or only faintly positive with Alcian blue and colloidal iron stains.

\section{Occurrence of giant cells in various diseases}

An analysis of the occurrence of synovial giant cells in the different arthritic conditions examined by us is presented in the Table (overleaf).

The giant cells were noted in sixteen out of 26 cases of rieumatoid, four out of twenty cases of tuberculous, and two out of eight cases of traumatic arthritis, and in one out of three cases of villonodular synovitis.

In rheumatoid arthritis these cells were seen only occasionally in two cases and more frequently in fourteen, five of which showed them in many foci. Their presence was unrelated to the presence or absence of the rheumatoid factor in the patient's serum. The age of the patient and the duration of the disease were also unrelated to their occurrence, except that they were not seen in cases of less than 1 year's duration. Although the giant cells usually occurred in the synovium showing mode:ate or marked proliferation of the synovial cells (Fig. 1), a few could at times be seen in specimens in which synovial cell proliferation was mild or absent. In one case many giant cells were present in a synovial membrane which showed only mild proliferation of synovial cells

In tuberculous arth itis, four out of sixteen cases showed synovial giant cells, and in two of these the cells weie numerous, with well-marked villous proliferation of the synovial intima. As has been noted already these giant cells could be easily distinguished from those which form part of the granulomatous inflammation of tuberculosis. Occasionally, a large Langhans's type of giant cell was noted in the synovial intima (Fig. 6, ove:'eaf) adjacent to a granuloma situated in the super:icial sub-synovial tissue. Synovial giant cells in tuber- 


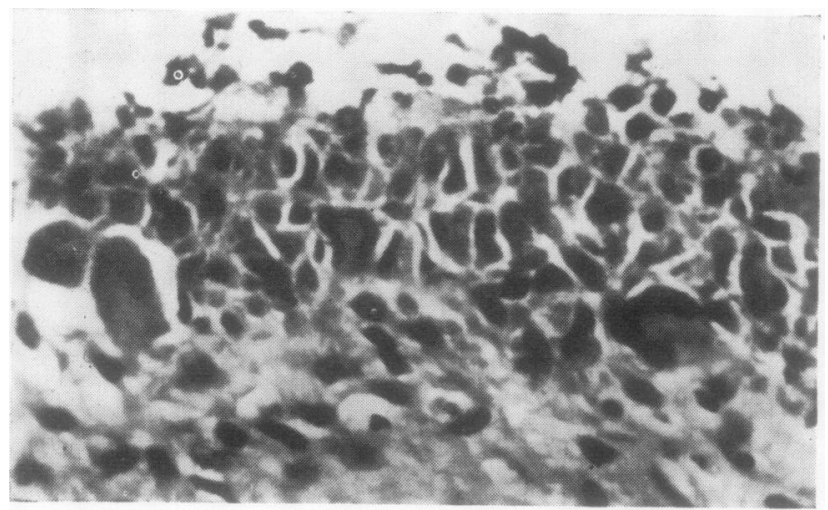

FIG. 5 Synovial membrane in rheumatoid arthritis, showing giant cells within the synovial intimal layer and just below the intima. Haematoxylin and eosin. $\times 530$.

Table Occurrence of synovial giant cells in various arthritic conditions

\begin{tabular}{|c|c|c|c|c|c|}
\hline \multirow[t]{2}{*}{ Disease } & & \multirow{2}{*}{$\begin{array}{l}\text { No. of } \\
\text { cases }\end{array}$} & \multicolumn{3}{|c|}{ Synovial giant cells present } \\
\hline & & & Occasional & + & ++ \\
\hline Rheumatoid arthritis & $\begin{array}{l}\text { Total } \\
\text { Sero-positive } \\
\text { Sero-negative } \\
\text { Serology not tested }\end{array}$ & $\begin{array}{r}26 \\
11 \\
11 \\
4\end{array}$ & $\begin{array}{l}2 \\
2 \\
0 \\
0\end{array}$ & $\begin{array}{l}9 \\
4 \\
3 \\
2\end{array}$ & $\begin{array}{l}5 \\
2 \\
2 \\
1\end{array}$ \\
\hline Tuberculous arthritis & & 20 & 2 & 0 & 2 \\
\hline Traumatic arthritis & & 8 & $\overline{1}$ & 1 & 0 \\
\hline Villonodular synovitis & & 3 & 0 & 1 & 0 \\
\hline Normal & & 10 & 0 & 0 & 0 \\
\hline Osteoarthritis & & 10 & 0 & 0 & $\overline{0}$ \\
\hline
\end{tabular}

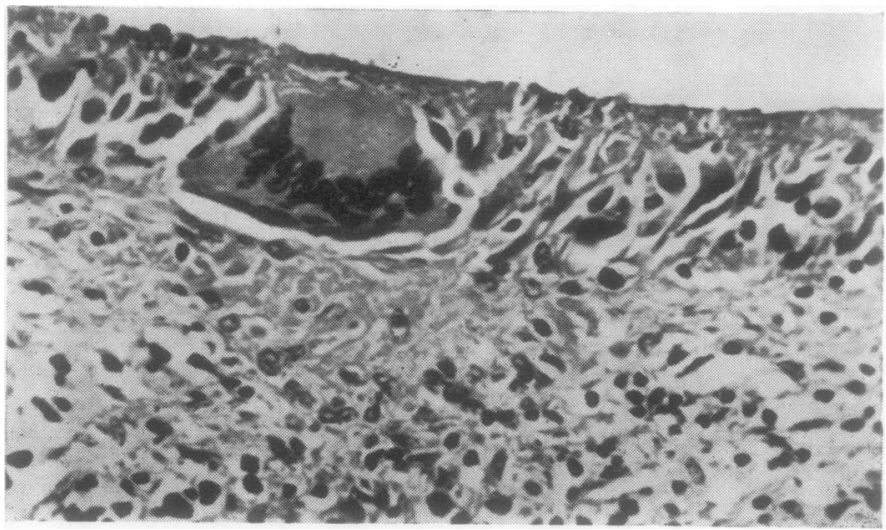

FIG. 6 Langhans's giant cell in the intimal layer in a case of tuberculous arthritis. Haematoxylin and eosin. $\times 530$.

culous arthritis were, however, present in areas with no granulomas. In tuberculous arthritis also, giant cells were not seen in cases of less than one year's duration.

Synovial giant cells were seen in two of the eight cases of non-specific synovitis; in both the cells were few and there was only mild to moderate synovial cell proliferation.

A small number of synovial giant cells containing haemosiderin pigment were present in one of the three cases of villonodular synovitis (Fig. 4).
None of the ten cases of osteoarthritis or of the ten subjects with normal synovial membranes showed any synovial giant cells.

\section{Discussion}

Diagnostic significance of synovial giant cells

Various types of giant cells are known to occur in the synovial membrane in different arthritic conditions. The most common of these is the foreign body type of giant cells seen in traumatic, rheuma- 
toid, osteo-, and gouty arthritis. Except in the last condition, the foreign body giant cells in synovial tissue form as a reaction to joint debris, especially fragments of articular cartilage and/or bone. The occurrence of Langhans's giant cells in granulomatous inflammation of the synovial tissue in tuberculosis and of giant cells in pigmented villonodular synovitis is also well known.

A distinctive giant cell found in the synovial membrane in cases of rheumatoid arthritis was designated 'synovial giant cell' by Grimley and Sokoloff (1966). These authors failed to find similar giant cells in normal subjects or in other arthritic conditions, and they considered that presence of synovial giant cells, which were seen only in seropositive cases, to be a distinctive feature of rheumatoid arthritis. Similar giant cells were also reported by Donald and Kerr (1968) in severe cases of rheumatoid arthritis, and because they also failed to find these cells in non-rheumatoid conditions they suggested that they might help in establishing the diagnosis of rheumatoid arthritis.

In the present study, although the giant cells were frequently present in rheumatoid arthritis both sero-positive and sero-negative, they were also seen in a few cases of tuberculous and non-specific arthritis and in one case of villonodular synovitis (Table). They were not present in normal synovial membrane or in cases of osteoarthritis. It appears, therefore, that although synovial giant cells are more frequent in rheumatoid arthritis, their presence should not be considered as specific for the disease. Muirden and Peace (1969) demonstrated the presence of similar giant cells in arthritis produced experimentally by the intra-articular injection of carragheenin, which again indicates their non-specific nature.

It should be noted that in our study the giant cells could be seen in both sero-positive and sero-negative cases of rheumatoid arthritis and that there was no correlation between their occurrence and the duration of the disease. It is interesting that the giant cells are usually seen in synovial membranes that show marked proliferation of the synovial cells, be it in rheumatoid, tuberculous, or non-specific arthritis; only occasionally do giant cells appear in synovium showing only mild proliferative activity or none.

\section{Origin of synovial giant cells}

On the basis of their combined light and electron microscopic study, Grimley and Sokoloff (1966) concluded that these giant cells are derived from the type-A synovial cells which are known to be phagocytic in nature. The presence of synovial giant cells in close proximity to the synovial intima (even at times within the synovial intimal layer) and also the frequent presence of transitional forms between synovial and giant cells also point to their origin from synovial lining cells. Type-A cells are also known to contain many lysosomal bodies. The presence of PAS-positive granules in the synovial giant cells appears to represent the lysosomal structures within them. Electron microscopical observation has also shown many lysosomal bodies within the synovial giant cells (Grimley and Sokoloff, 1966).

The precise significance of their presence cannot yet be ascertained. It is considered likely that they form as a reaction to some chronic injury directed primarily towards the synovial lining cells, resulting in synovial hyperplasia and giant cell transformation. The offending agent may be a micro-organism in the form of mycoplasma (Bartholomew, 1965) or diphtheroid bacillus (Stewart, Alexander, and Duthie, 1969), the two agents suggested as possible infective organisms in rheumatoid arthritis, tubercle bacillus in tuberculous synovitis, foreign body in non-specific arthritis, and some undetermined agent in villonodular synovitis.

\section{Summary}

The synovial membrane from normal subjects and patients with arthritic conditions were studied for the presence of distinctive synovial giant cells. Although synovial giant cells were most frequently seen in cases of rheumatoid arthritis, they were also present in a small number of cases of tuberculous arthritis, traumatic arthritis, and villonodular synovitis. The presence of synovial giant cells is not therefore considered to be specific for rheumatoid arthritis.

\section{References}

Allison, N., AND Ghormley, R. K. (1931) 'Diagnosis in joint disease. A clinical and pathological study of arthritis'. Wood, New York; Oxford University Press, London.

BARTHOlOMEW, L. E. (1965) Arthr. and Rheum., 8, 376 (Isolation and characterization of mycoplasmas (PPLO) from patients with rheumatoid arthritis, systemic lupus erythematosus and Reiter's syndrome).

Collins, D. H. (1949) 'The Pathology of Articular and Spinal Diseases'. Arnold, London.

COPEMAN, W. S. C. (1964) 'Textbook of the Rheumatic Diseases', 3rd ed. Livingstone, Edinburgh.

Donald, K. J., AND KerR, J. F. R. (1968) Med. J. Aust., 1, 761 (Giant cells in the synovium in rheumatoid arthritis). 
Gardner, D. L. (1965) 'Pathology of the Connective Tissue Diseases'. Arnold, London.

Grimley, P. M., AND SoKoLoff, L. (1966) Amer. J. Path., 49, 931 (Synovial giant cells in rheumatoid arthritis). Hirohata, K., and Kobayashi, I. (1964) Kobe J. med. Sci., 10, 195 (Fine structures of the synovial tissues in rheumatoid arthritis).

McManus, J. F. A., AND Mowry, R. W. (1960) 'Staining Methods: Histologic and Histochemical', p. 135. Hoeber, New York.

Muirden, K. D., AND Peace, G. (1969) Ann. rheum. Dis., 28, 392 (Light and electron microscopic studies in carragheenin, adjuvant, and tuberculin-induced arthritis).

Ropes, M. W., Bennett, G. A., CoBb, S., JACOX, R., AND Jessar, R. A. (1959) Ibid., 18, 49 (Diagnostic criteria for rheumatoid arthritis: 1958 revision).

Stewart, S. M., Alexander, W. R. M., AND DuthiE, J. J. R. (1969) Ibid., 28, 477 (Isolation of diphtheroid bacilli from synovial membrane and fluid in rheumatoid arthritis). 